\title{
INTRODUCTION
}

\section{Education and the discourse of global neoliberalism}

This special issue of Language and Intercultural Communication on 'Education and the discourse of global neoliberalism' has its origins in a two day symposium which was held at the UCL Institute of Education in 2014. Several presenters at the symposium, which focused mainly on education in the Anglophone world, have contributed to this special issue in which we have also incorporated papers addressing the educational situation in a range of Asian contexts. In doing this we aim to show that neoliberalism is a complex phenomenon which takes on local characteristics in diverse geopolitical, economic and cultural settings, while retaining a core commitment in all its manifestations to market fundamentalism. Despite the US financial crisis of 2008 and the subsequent implementation of austerity in the massively indebted nations of the European Union, neoliberalism has shown itself to be a remarkably resilient and mercurial phenomenon. It is also much talked about and theorized across a range of disciplines. The editors' preface to a recent book on the topic (Flubacher \& Del Percio, 2017) points out that between 2002 and 2005 there were around a thousand academic articles a year being published in which the term was used, with a ninefold annual rise in usage in the years following the 2008 financial crisis. With such a profusion of commentary and theorization, it is only to be expected that opinions differ as to the nature of the phenomenon. Brenner, Peck and \& Theodore (2010) have described this intellectual climate, which is worth quoting at length, as follows:

[N] eoliberalism is understood variously as a bundle of (favoured) policies, as a tendential process of institutional transformation, as an emergent form of subjectivity, as a reflection of realigned hegemonic interests, or as some combination of the latter. Some scholars see these trends as signalling an incipient form of regulatory convergence or hegemony; others continue to call attention to significant flux and diversity, even if they cannot yet determine a singular countercurrent. The boldest formulations position neoliberalism as a 'master concept', or as a byword for an ideologically drenched form of globalization. Those more sceptical of such totalizing visions prefer to portray neoliberalism as a hybrid form of governmentality, or as a context-dependent regulatory practice. Perhaps not surprisingly, faced with these conflicting thematic evocations and methodological tendencies, others have concluded that 'neoliberalism' has become a chaotic conception rather than a rationally defined abstraction, and have thus opted to avoid using it altogether. (Brenner, Peck \& Theodore, 2010: 183)

They conclude however that neoliberalism, despite these varying perspectives, remains a useful term to describe the current phase of capitalism, and they argue that it is best understood as a 'variegated' phenomenon which is 'simultaneously patterned, interconnected, locally specific, contested and unstable' (Brenner et al., 2010: 184). As editors of this special issue we subscribe to this assessment, while taking the view that neoliberalism is fundamentally a 'class project [...] designed to restore and consolidate capitalist class power' (Harvey, 2010: 10). We also see neoliberalism - again following Harvey (2005: 2) - as 'a theory of political economic practices that proposes that human well-being can best be advanced by liberating individual entrepreneurial freedoms and skills within an institutional framework characterized by strong private property rights, 
free markets, and free trade' (although we feel that this relationship may be changing); and that it promotes in contradiction to its declared stance on market regulation a strongly interventionist state whose role is 'to create and preserve an institutional framework appropriate to such practices' (ibid.).

In addition to being a market-based and governmentally-authoritarian phenomenon, it is clear that neoliberalism is also a linguistic and intercultural phenomenon as well. Taking the intercultural dimension first, we may note that it was first 'cultured' in an international Colloquium named after the journalist and political commentator, Walter Lippmann, in Paris in 1938. This was an interdisciplinary international event which was held with the aim of coordinating global action against the concept of the 'planned economy' in Communist Russia, and related to this the ideas of demand management and economic stimulus which were to be found in Keynes' General Theory of Employment (1936). Keynes' diagnosis in the General Theory of what had caused the Wall Street Crash of 1929 and the ensuing Great Depression of the 1930s were gaining wider currency, and part of the rationale of the international attendees of the Lippmann Colloquium, which included Friedrich Hayek, Ludwig von Mises and Walter Lippmann himself, was to formulate a 'new liberalism' which would be able to counter this. The term 'neoliberalism' as an antidote to Keynesianism and as a rejection of 'old' liberalism originates with this meeting (Stedman-Jones, 2012). Lippmann's book The Good Society (1937) was the required preparatory reading. In the book, Lippmann took the view that classical laissez-faire liberalism needed revising if what he saw as a slide towards state totalitarianism was to be avoided. However, the outbreak of the Second World War put a halt to the activities of the colloquium's organizers, and it was not until after the war and the first meeting in 1947 of what became known as the Mont Pèlerin Society (MPS) that attempts were made to resurrect the project first mooted in 1938, but now with still greater urgency. The main purpose of the MPS - a by now much expanded grouping of European and American émigré intellectuals, including Hayek, von Mises, Karl Popper and Milton Friedman - was as before to rescue the pre-war tradition of liberal economic thinking from the ideological oblivion to which it had been consigned since the Great Depression and still more so since the end of the war. However, unlike the classical laissez-faire and 'invisible hand' market liberalism originally associated with Adam Smith and David Ricardo, neoliberalism held that the market required constant ideological maintenance as well as active intervention by the state. From its inception, the MPS took the view that a strong legal and institutional apparatus was necessary to ensure the proper 'free' functioning of the market. The first statement of their aims in 1947 contained the following key statement:

The preservation of an effective competitive order depends upon a proper legal and institutional framework. The existing framework must be considerably modified to make the operation of competition more efficient and beneficial. The precise character of the legal and institutional framework within which competition will work most effectively and which will supplement the working of competition is an urgent problem on which continued exchange of views is required (in Plehwe, 2009: 23).

Here we see what is in effect the importance of the state being underlined for the success of the project. It is important to recall how marginal views such as these were in 1947. Karl Popper, who attended the first meeting of the MPS, went on record as saying 'The present position is one where 
we nearly despair' (Plehwe, 2009: 16), so sure were many of those who drew up its charter that Soviet-style 'socialism', or at least some kind of state-administered 'planned' capitalism in the west, was about to triumph. As it turned out, they were not so far wrong on the latter, as Keynes' ideas emanating from the General Theory came to dominate the post-war settlement in the nations of the west, as well as the organization of the global economy. Three years previously, in The Road to Serfdom (1944 [2001]), written in Britain just as a state-sponsored 'welfare state' was being proposed, Hayek argued that Soviet-style planning - including 'arm's length' planning of the Keynesian kind - was a recipe for modern slavery, and spelled the end of 'individualistic civilisation', which for Hayek had up to then been the greatest contribution of Europe to the world. Brenner, Peck \& Theodore capture well the diverse intercultural and 'transnational' threads that were woven into the fabric of the emerging neoliberal world view:

[N]eoliberalism built on the dispersed ideational resources found in the situated liberalisms of Austrian economics, German Ordoliberalism, Manchesterism, and Chicago-style counter-Keynesianism. Neoliberalism was thus effectively born in an already transnationally networked, intellectually hybrid and unevenly developed ideological form. (Brenner, Peck \& Theodore, 2010: 211-212)

By the time The Road to Serfdom was published, Keynesianism was in the ascendant and in its various formulations was to maintain its hegemony, particularly in Britain and the United States, until the mid-1970s. Neoliberal ideas, not unexpectedly, continued to be presented as a an ideological and economic counterpoint to Keynesianism by the global network of ideologically-conservative academics, journalists, business leaders and politicians who made up the increasingly elite membership of the MPS, and of the diverse organizations and 'think tanks' which were globally affiliated to it. The MPS represented an ideological 'counter-culture' and philosophy around which conservative capitalists disillusioned with the constraints which the post-war settlement had placed on private investment and profit felt able to coalesce. The network has been referred to by Philip Mirowski (2013) as 'the neoliberal thought collective' - a term which captures something of the single-mindedness of the MPS and its affiliated groups from their inception up to the present day. Contemporary examples include the Ayn Rand Institute (US), the Centre for Policy Studies (UK), and La Fundación para el Análisis y los Estudios Sociales (Spain). It would not be until the 1970s and the crisis of global capitalism in 1973-74, when oil prices quadrupled, that conservative and mostly 'rightwing' politicians and their allies in business began to pay greater intellectual heed to the arguments being put forward by leading MPS thinkers. Up until that time, conservative politicians in the west had largely accepted the logic of the Keynesian economic mechanism. But with the oil crisis, rising unemployment and rampant inflation, they became attracted to radical economic alternatives which coincidentally chimed with their largely individualist, property-based, and traditionalist world view. They were also persuaded by the idea that an economic downturn need not be at the expense of the state, because of the neoliberal claim that there was a natural rate of unemployment. The elections of self-proclaimed 'New Right' politicians such as Margaret Thatcher and Ronald Reagan would prove to be the MPS's first major advance in the capitalist west - although the Society had already had a major success in Chile, where the US-sponsored coup d'etat against Salvador Allende's 
democratically-elected socialist government in 1973 (Winn, 2010) led to the implementation of economic policies which had been incubated at the University of Chicago under the direction and tutelage of Arnold Harberger and Milton Friedman, both of whom were professors there. The massive human rights abuses and deep social inequalities which were promulgated by the Chicago experiment in Chile were mostly ignored by conservative political observers in the west, as well as being largely disowned by Friedman himself, who denied any responsibility for the severity of the social dislocation and the enormous state terror which ensued. This was despite, along with Harberger, having personally signed off on the economic plan himself (Peck, 2010). Of more interest to MPS converts was what it meant for the capitalist state. With the elections of Margaret Thatcher and Ronald Reagan in the UK and US, economic policies were initiated with the purpose of bringing about what Bourdieu referred to as 'the destruction of all collective structures that could serve as an obstacle to the logic of the pure market' (1988). This involved the incremental rolling back of as many forms of state welfarism as electorates could be made to bear, and the relentless commodification and individualization of more and more aspects of social life (Harvey, 2005). Ideologically this was underpinned by the mass circulation of ideas in the media, at political party conferences and in academic writing suggesting there was no alternative to the new economic order (Giddens, 2000); that the poor were responsible for their own poverty (Murray, 1984); that economic austerity post 2008 was (and remains) a necessity (Reinhart and Rogoff, 2010); that social class is an outdated way of looking at contemporary society in which there are only 'individual men and women' (Thatcher, 1987); and that 'the system of private property is the most important guarantee of freedom' (Hayek, [1944] 2001: 108). In the supposed absence of any fiscal alternative following the financial catastrophe of 2007-8 in Europe and the US, neoliberal strictures have only become more virulent, as a solution to the on-going crisis is sought in the more systematic application of the very policies which brought the crisis about. Not being confined to the west, although emanating from it, this is a practice which is being mirrored in Asian contexts, such as South Korea, Singapore, Hong Kong and Japan, where there has been a high commitment to neoliberal economic models since the 1980s, and where income inequalities are now also increasingly acute.

At the same time, as we have stated above, neoliberalism is also a linguistic phenomenon. On the one hand there is the language of neoliberalism itself, and on the other there is the role of certain languages under neoliberalism. With regard to the former, there is the way in which all kinds of institutional discourses and everyday speech have been colonized by terms normally associated with the market. Thus words such as quality control, impact, knowledge transfer, human capital, deregulation, entrepreneur, choice, customer, stakeholder (the list is potentially endless) have become pervasive, at times acquiring new meanings in the process of proliferation (Fairclough, 1993, 2000; Holborow, 2007, 2012; Collini, 2017). Marnie Holborow (2012) has written insightfully about what she calls neoliberal keywords and she argues that such items serve an important ideological function. Thus, she suggests, such words 'have special meanings and associations within the framework of neoliberal ideology and reflect a version of reality which promotes the interests of capital' (p. 41); that they 'often involve a process of re-semanticisation (or meaning-stretching) which allows for the extension of semantic boundaries into new fields for ideological purposes' (ibid.); and 
that they 'are subject to evaluation and multiaccentuality, formed through social standpoints and the relationship of the ideology to events in the real world' (ibid.). A good example of the kind of thing Holborow is talking about can be seen in the neoliberal uses of a work like choice. In the UK today, as education and public health services are increasingly marketized, parents and patients are frequently told that they are being offered choice, in which the destruction of a public good for private profit is frequently deliberately obfuscated. However, the choice of being able to send one's child to an under-resourced state school or a privatized academy sponsored by business is not a real choice.

Choice in this lexicon is in fact a proxy for creeping privatization. Hence the increased involvement of the private subcontractors within other public services such as housing, transport, the criminal justice system, and health.

In a recent book on the marketization of higher education in the UK - Speaking of Universities - Stefan Collini (2017) notes that for some commentators concern about language being used in the way Holborow describes is erroneous - we are only talking about words after all. Dismissing this, Collini makes an important point about the role language plays:

It would not require any particular fancy philosophical footwork to establish that our experience of the world is in part constituted by the categories we use. Words are not some kind of decorative wrapping paper in which meaning is delivered [...] Concepts colonise our minds and we become used to thinking about ourselves and our world in their terms; our actions are only identifiable as this action rather than that action in terms of the language in which we describe them (Collini, 2017: 3).

But unlike the fantasy language of Orwellian Newspeak (itself a misrepresentation of the nature of language) in which the meanings of words are determined by totalitarian language planners whose aim is the eradication of concepts such as political freedom, the ideological work of neoliberal newspeak is not guaranteed - although it is not without its effects. But as Holborow (2012: 54) suggests, the representations such language seeks to construct and the meanings it attempts to marshal are often contradictory, illogical or banal - wherein, she argues, 'lies the potential for ideological contestation'. From this perspective, neoliberal ideology itself is seen as inherently unstable (because capitalism is) - the fault lines are always in danger of becoming visible when language is looked at critically, or when events in the material world change in such a way that ideological recalibration is required.

With regard to the role of individual languages under neoliberalism, again the market plays a determining role - 'edu-businesses' of the kind described by Stephen Ball (2012), which provide language courses, pedagogical materials and global testing services, brand their products in promotional materials as though they were commodities like any other in the marketplace, presenting them as a means of 'adding value' to an individual's skill-set (Gray, 2010; Block \& Gray, 2018; Pegrum, 2004; Simpson, this issue). Under neoliberalism there is a frequently noted 'resignification of language' (Flubacher and Del Percio, 2017: 7) - away from previously established views of language (e.g. as resource for meaning making, self-expression and communication, as a means of accessing cultural products and (in the case learning additional languages) relativizing one's world view [Kramsch, 1993]) - towards a much more instrumental and economistic perspective. This 
is particularly noticeable with regard to English as it has become a global lingua franca - although clearly it is also the case for other languages as well. The global spread of English, which is itself a 'global' industry, has in turn created the conditions in which internationalized capital and national education systems across the world not only excessively valorize English, but also in which the nations of the Anglophone core excessively valorize monolingual instrumentalism. In the UK and the US, for example, the global spread of English has led to an active disinterestedness in the learning of other languages, since the popular perception is that 'everyone speaks English'. In the process, often with the explicit encouragement of right-wing agitators in the political establishment and the Fourth Estate, English native speakers have been made more monolingual, and with it, more insular and lacking in intercultural curiosity, as the election of Donald Trump in the US and the UK's Brexit vote have shown.

Education, from primary through to tertiary level, has been particularly important to neoliberalism. We suggest that there are two main reasons for this. In the first place, in those settings in which education was traditionally the preserve of the state, institutions were seen as ripe for the application of market principles as a means of encouraging competition for access to decreasing reserves of public money, and as a mechanism for 'driving up standards'. Regimes of inspection in schools, the frequent testing of pupils and the publications of test scores force institutions to compete for 'customers' - the same goes for universities which are ranked nationally and globally on the basis of a range of criteria such as the productivity of their researchers, quality of teaching, student experience and so on. Perhaps more significantly, from the perspective of neoliberal government, education is important because its function, as neoliberals see it, is the production of subjects with the knowledge and dispositions which are appropriate for servicing the economy. Hence the application of market principles entailing the elimination of subject areas deemed unprofitable, the introduction of standardized modular curricula, the increased use of English as a medium of instruction (EMI) as a means of attracting international students, the positioning of lecturers as service providers, the use of student evaluations as a mechanism for ensuring 'customer satisfaction', and - in the case of teacher education - a narrowing of the professional knowledge base and a focus on the efficient delivery of narrowly defined and easily measured content. Sadly, these are but a few of the many changes brought about by the neoliberalization of education.

In the articles comprising this special issue, these and other issues are explored in some considerable depth. The initial three articles focus on the Asian context. Joseph Park argues that the media play a key role in promoting and rationalizing the neoliberalization of education by mediatizing particular ideas of what the future will be like. His analysis of two media texts - one Korean, one Singaporean - shows how the future is constructed in terms of extreme volatility and unpredictability in ways which work to rationalize neoliberal transformations of education that are taking place in the present. In their article, Carlos Soto and Miguel Pérez-Milans draw on their fouryear ethnographic study carried out in a low-prestige Hong Kong secondary school which addressed the difficulties the school was facing in meeting the minimum government-required student intake in order to keep maximum public funding by setting up an EMI section to attract working-class students 
from migrant backgrounds. Marketed as pedagogically progressive by the school, their analysis shows how the EMI pedagogy unexpectedly became a resource for advancing ethnic-group activist concerns, leading to unpredicted tensions and forms of inequality. The final research article by William Simpson looks at advertising for commercial English language schools in Japan (eikaiwa). The article argues that the erasure of teachers' labour from advertising contributes to the commodity fetishism that divorces commodities (in this case the language lesson itself) from the labour that produces them, a fetishism which, it is argued, permeates the language ideology of neoliberal Japan.

Moving from the Asian setting to an Irish one, Marnie Holborow addresses the rise of human capital theory and she argues, with reference to the dramatic falls in public spending in Ireland, that human capital theory functions ideologically as a strategy of displacement whose aim is to shift the focus of responsibility for educational and employment outcomes from the social to the individual. The final three articles move across the Irish Sea to address the deleterious situation of education in the UK. The first, which is by two of the present editors, John O'Regan and John Gray, analyzes the discourse of the UK government's Research Excellence Framework for universities and argues that it functions as a neoliberal mechanism for the promotion of competition and service to the economy whose ultimate purpose is the neutralization of the university as a centre of independent knowledge creation and learning, and hence as a potential locus of intellectual opposition to the neoliberal hegemony. In similar vein, Alison Sealey, from an autobiographical perspective, considers the differential placements of social actors in the contemporary neoliberal university, and explores how the options available change in relation to alterations in the structured social relations among students, those in precarious conditions of employment, and those occupying more influential roles in the institution. John Hardcastle and John Yandell turn their attention to secondary high schools in their contribution and to the neoliberal traducing of the history of progressive education in the UK. Focusing on the teaching of English in the state school sector, the authors make the case for an alternative history of this tradition, the awareness of which, they argue, provides the means to confront the contradictions in the neoliberal educational project today. The special issue is brought to an end by a short discussion piece by David Block in which he reflects on the complexity of issues raised by the preceding articles. He concludes with the observation that as capitalism inevitably exhausts itself the strategies of resistance in education called for in this special issue will, of necessity, need to be matched by strategies of action as the possibility of genuine structural change presents itself.

\section{Notes on contributors}

John Gray is Reader in Languages in Education at UCL Institute of Education, University College London. He has published in Applied Linguistics, ELT Journal, Language Teaching Research and the Journal of Multilingual and Multicultural Development. He is the co-author of Neoliberalism and Applied Linguistics (2012), written with David Block and Marnie Holborow, and of Social Interaction and English Language Teacher Identity (2018), co-authored with Tom Morton. From 2013-15 he was a grant holder for the ESRC-funded seminar series Queering ESOL: towards a cultural politics of LGBT 
issues in the ESOL classroom (ES/L001012). He is currently editing a special issue of Gender and Language with Melanie Cooke on 'Intersectionality, Language and Queer Lives'.

John P. O'Regan is Reader in Applied Linguistics at UCL Institute of Education, University College London. He specializes in English as a global language, intercultural communication, and critical discourse analysis, and is the author of articles on a wide range of topics in cultural studies and applied linguistics. He has published in several journals, including the Journal of Applied Linguistics, Language and Intercultural Communication, Critical Discourse Studies, and the Journal of the Royal Asiatic Society Hong Kong. He was a co-editor of Intercultural Dialogue: Questions of Research, Theory and Practice, Routledge (2016), and of Travelling Languages: Culture, Communication and Translation in a Mobile World, Routledge (2014). He is the author of the article 'English as a Lingua Franca: An Immanent Critique,' Applied Linguistics, 35(5), (2014), and with William Simpson, of 'Fetishism and the Language Commodity: A Materialist Critique,' Language Sciences (2018). He is currently completing a book on Global English and Political Economy, also for Routledge.

Catherine Wallace is Emerita Professor of Education in the Department of Culture, Communication and Media at UCL Institute of Education, University College London. She has worked in Higher Education in the UK for 37 years and, before then, lectured in English as a foreign language in Italy and Brazil. Her areas of interest are sociolinguistics, critical literacy, multilingualism and classroom interaction, in particular language and identity and the negotiation of rights in multilingual classrooms. She is on the Advisory Board for Language Issues, the journal of NATECLA (National Association for Teaching English and Other Community Languages to Adults). She is the author of a number of books and articles on literacy, including Critical Reading in Language Education and a recent book: Literacy and the Bilingual Learner: Texts and Practices in London Schools.

\section{References}

Ball, S. J. (2012) Global Education Inc.: New Policy Networks and the Neo-liberal Imaginary. Abingdon: Routledge.

Block, D. and J. Gray (2018) 'French language textbooks as ideologically imbued cultural artefacts: Political economy, neoliberalism and (self) branding', in Coffey, S. and U. Wingate (eds.) New Directions for Research in Foreign Language Education. Abingdon: Routledge.

Bourdieu, P. (1998, December). Utopia of Endless Exploitation: The Essence of Neoliberalism. Le Monde diplomatique. Retrieved from https://mondediplo.com/1998/12/08bourdieu

Brenner, N., Peck, J. \& N. Theodore (2010) Variegated Neoliberalization: Geographies, Modalities, Pathways. Global Networks, 10, 182-222.

Collini. S. (2017). Speaking of Universities. London: Verso. 
Del Percio, A. \& M. Flubacher (Eds.) Language, Education and Neoliberalism. Bristol: Multilingual Matters.

Fairclough, N. (1993). Critical Discourse Analysis and the Marketization of Public Discourse: the Universities. Discourse \& Society, 4(2), 133-168.

Fairclough, N. (2000) New Labour, New Language. London: Routledge.

Giddens, A. (2000) The Third Way and its Critics. Cambridge: Polity Press.

Gray, J. (2010) The Construction of English: Culture, Consumerism and Promotion in the ELT Global Coursebook. Basingstoke: Palgrave Macmillan.

Harvey, D. (2005). A Brief History of Neoliberalism. Oxford: Oxford University Press.

Harvey, D. (2010). The Enigma of Capital: and the crises of capitalism. London: Profile Books.

Hayek, F. A. ([1944] 2001). The Road to Serfdom. London: Routledge.

Holborow, M. (2007). Language, ideology and neoliberalism. Journal of Language and Politics 6, 5173

Holborow, M. (2012). What is neoliberalism? Discourse, Ideology and the Real World. In D. Block, J. Gray, \& M. Holborow (Eds.), Neoliberalism and Applied Linguistics (pp. 33-55). London: Routledge.

Kramsch, C. (1993) Context and Culture in Language Teaching. Oxford: Oxford University Press.

Keynes, J. M. (1936). The General Theory of Employment, Interest and Money. London: Macmillan and Co., Limited.

Lippmann, W. (1937) The Good Society. Boston, MA: Little, Brown \& Co.

Mirowski, P. (2013). Never Let a Serious Crisis Go to Waste: How Neoliberalism Survived the Financial Meltdown. London: Verso.

Murray, C. (1984) Losing Ground: American Social Policy 1950-1980. New York, NY: Basic Books.

Peck, J. (2010). Constructions of Neoliberal Reason. Oxford: Oxford University Press.

Pegrum, M. (2004) 'Selling English: advertising and the discourses of ELT'. English Today 77, 20 (1): 310.

Plehwe, D. (2009) Introduction. In Plehwe, D. \& P. Mirowski (Eds.) The Road from Mont Pèlerin: the making of the neoliberal thought collective. Cambridge, MA: Harvard University Press, pp.1-44.

Reinhart, C. and K. Rogoff (2010) 'Growth in a Time of Debt', American Economic Review, 100 (2): 573-78. 
Stedman Jones, D. (2012). Masters of the Universe: Hayek, Friedman, and the Birth of Neoliberal Politics. Princeton \& Oxford: Princeton University Press.

Winn, P. (2010) 'The Furies of the Andes: Violence and Terror in the Chilean Revolution and Counterrevolution', in Grandin, G. \& G. M. Joseph (Eds.) A Century of Revolution. Durham, NC: Duke University Press, pp. 239-275.

John Gray

Department of Culture, Communication and Media, UCL Institute of Education, London, UK john.gray@ucl.ac.uk

John P. O'Regan

Department of Culture, Communication and Media, UCL Institute of Education, London, UK john.oregan@ucl.ac.uk

Catherine Wallace

Department of Culture, Communication and Media, UCL Institute of Education, London, UK cathie.wallace@ucl.ac.uk 